\title{
Family Comes First: An Investigation on Entrepreneurial Intention among Chinese Indonesian Gen Z
}

\author{
Kunthi A. Kusumawardani \\ Faculty of Business, President University, Bekasi, Indonesia \\ kunthi.kusumawardani@president.ac.id* \\ Richard \\ Faculty of Business, President University, Bekasi, Indonesia \\ albertusrichard@ymail.com
}

\begin{abstract}
This study discusses the influence of family background and education in entrepreneurship on the entrepreneurial self-efficacy in shaping the entrepreneurial intention among Chinese Indonesian Gen Z. Through the application of the Theory of Planned Behaviour (TPB), this research employed quantitative method design. This current study uses Structural Equation Modelling (SEM) analysis on 202 individuals. Finding indicates that Family Background and Entrepreneurship Education affect Entrepreneurial Self-Efficacy, and Entrepreneurial Self-Efficacy mediates the relationship between Family Background and Entrepreneurship Education in Entrepreneurial Intention. However, Family Background and Entrepreneurship Education do not have direct influences towards Entrepreneurial Intention. Based on the finding, it can be determined that Family Background and Entrepreneurship Education will stimulate a high Entrepreneurial Self-Efficacy which leads to Entrepreneurial Intention. Thus, this study suggests the stakeholder in education in Indonesia to create an entrepreneurship-based system in the education curriculum to equip students with knowledge of entrepreneurship and develop the skills not only to discover the business opportunity, but also to create a sustainable one, and at the same time encouraging them to have self-confident in their capability in becoming thriving entrepreneurs. This study provides an insight of the Entrepreneurial Intention among Chinese Indonesian Gen $\mathrm{Z}$ which has never been investigated in the past. Additionally, it contributes the empirical evidence of Entrepreneurial SelfEfficacy role in in transforming Family Background and Entrepreneurship Education into Entrepreneurial Intention.
\end{abstract}

Keywords: Family Background; Entrepreneurship Education; Entrepreneurial Self-Efficacy; Entrepreneurial Intention; Chinese Indonesian; Generation Z

\section{Introduction}

Indonesia is the fourth most populous country in the world (World Population Review, 2019), and with such position, the problem encountered by the country are various. Unemployment is remaining a daunting issue for Indonesia. Although in 2018 the number of unemployment is decreased than the previous five years with $5.34 \%$ of the total labour force, the number is still quite high when being compared with neighbouring countries like the Philippines with 5.2\%, Malaysia with $3.3 \%$, and even Thailand with only $0.8 \%$ (Trading Economics, 2018). The main challenge

*Corresponding Author 
faced by Indonesia in the unemployment rate is the encouragement to create job creation for youth or freshly graduated (Indonesia Investments, 2018).

Entrepreneurship has been frequently linked with the stimulation of economic growth. Carree and Thurik (2010) mentioned that entrepreneurship performs as a channel for change and innovation, which can generate economic growth. This is also the reason why entrepreneurship has been one of the main focuses for the government in creating the policy (Wennekers and Thurik, 1999; Acs and Szerb, 2007). Besides generating economic growth, entrepreneurship has also been proven to have a connection to reduce the number of unemployment (Owualah, 1999; Audretsch, Carree, and Thurik, 2008). In Indonesia, the entrepreneurship rate remains low, as the country rank 94 th out of 137, as stated by the minister of trade, Enggartiasto Lukita (Dwinanda, 2018). Although Indonesia's entrepreneurship rate is already exceeding the international rate of $2 \%$, in comparison with other countries, Indonesia is still rather low. Malaysia, for instance, has reached 5\%, Singapore with $7 \%$, and China with $10 \%$, while Indonesia has just reached $3.1 \%$ of the total workforce (Lestari \& Darmawan, 2018).

Entrepreneurial intention is a common term in the field of entrepreneurship, and it keeps evolving field of research (Liñán \& Fayolle, 2015). One of the most popular theoretical frameworks to measure Entrepreneurial Intention is the Theory of Planned Behaviour (TPB) by Ajzen (1991). The theory explained that intentional behaviour must take into account personal and social factors, and a more positive attitude will make the intention more feasible to be carried out (Liñán, RodríguezCohard, \& Rueda-Cantuche, 2010). Based on the Global Entrepreneurship Monitor Report, Indonesia ranked the second-highest among ASEAN countries in the entrepreneurial intention with $35 \%$, and $62 \%$ of the respondents believed that to start a business, they need to be equipped with skills, knowledge, and experience (Santoso A. B., 2014).

Studies have been conducted to find out the determinants of Entrepreneurial Intention, for instance, the factor of Entrepreneurship Education (Gerba, 2012; Pangestu, Nicky, and Kumar, 2014; Fayolle and Gailly, 2015; Puni, Anlesinya, and Korsorku, 2018; Kumar and Dedi, 2019) and Family Background (Zellweger, Sieger, and Halter, 2011; Altinay, Madanoglu, Daniele, and Lashley, 2012; Ranwala, 2016; Farrukh, Khan, Khan, Ramzani, and Soladoye, 2017; Kumar and Dedi, 2019). Studies believed that the exposure of entrepreneurship education would shape a more significant entrepreneurial intention among students (Gerba, 2012; Puni, Anlesinya, and Korsorku, 2018; Kumar and Dedi, 2019). Despite the fact that ethnicity has an influence on generating occupational stratification and entrepreneurship (Kerr \& Mandorff, 2015), there are only a few focusing on both family business background and ethnicity. Most studies that have been conducted were only focusing on the relations between the family background of having a family business and Entrepreneurial Intention (Ranwala, 2016; Farrukh, Khan, Khan, Ramzani, and Soladoye, 2017). Sutanto and Nurrachman (2018) explored the meaning of entrepreneurship among ethnic groups in Indonesia, but not on the Entrepreneurial Intention.

Although not all Chinese Indonesian business is successful, they are stereotyped as skilled in a trade, due to the children are taught to be an entrepreneur since they are young (Heriyanto, 2019). The stereotype is actually not entirely wrong, as listed in the 150 richest Indonesians by Globe Asia, the top 4 richest people are Chinese 
Indonesian entrepreneurs; namely Robert Hartono, Eka Tjipta Widjaja, Anthoni Salim, and Susilo Wonowidjojo (Globe Asia, 2018). The importance of ethnicity, especially Chinese Indonesian in the entrepreneurship, has been discussed by Koning (2007). She mentioned that both the younger and older generation of Chinese Indonesian entrepreneur's emphasis on the mentality and practice of business the significance of 'being Chinese'. This has been confirmed by numerous entrepreneur associations which based on the Chinese Indonesian ethnicity to build connection, referral, and networks with existing and potential investors or business partners (Setijadi, 2016).

This study has several significances. First of all, this study helps to enhance the knowledge of Entrepreneurial Intention in Indonesia, especially among the generation of digital natives or gen $\mathrm{Z}$. The study of gen $\mathrm{Z}$ in the entrepreneurship is rather necessitated, due to the fact that they are ready to become the most entrepreneurial generation in history (Powers, 2018; Wolinsky, 2018). Hence, this study is able to universalise the building of Entrepreneurial Intention model. Second of all, through the variable of entrepreneurship education and the finding that indicates its influence in encouraging intention to be entrepreneurs, this research is able to advise the importance of assimilation of entrepreneurship education to the educational institution's programs. Third of all, through this study, government as the policymakers may gain a critical understanding of feasible supports for Gen $\mathrm{Z}$ to develop their entrepreneurial career. Conclusively, this research can be used as a reference for future studies, especially because this research takes a specific empirical approach to family background ethnicity.

This research is organised as follows. First, it portrays the background of the study. Secondly, it describes the theoretical framework and the relations between Entrepreneurship Education, Family Background, Self-Efficacy, and Entrepreneurial Intention. Thirdly, methods and hypothesis of the research are presented. Fourthly, the result is discussed. The last is the conclusion and implication of the research.

\section{Literature Review and Hypothesis Development}

\subsection{Family Background}

Family background plays a vital role for an individual to become a good entrepreneur in a family business (Matthews \& Moser, Longitudinal investigation of the impact of family background and gender on interest in small firm ownership., 2016; Kumar \& Prameswari, 2018). Family background is the responsibility of parents to influence and make a positive impression on children to start building good traits, positive attitudes, and ethical conduct (Marques, Santos, \& Justino, 2018). Furthermore, Shittu, Ayodele, Dosunmu, and Zainab (2014) said that family gives the most education to the children, which is managing and developing a business.

The perception of entrepreneurship is influenced by the attitude of family members, as Drennan, Kennedy, and Renfrow (2005) stated that childhood experience factors of parental ownership of a business, difficult childhood, and frequent relocation influenced the entrepreneurial intention. Meanwhile, ethnicity in the family background has been conducted by Basu (2004) in the U.K., and it found that the interaction between ethnicity, culture, and class in the family background create complexity in the aspiration of entrepreneurship. Basu (2010) also mentioned that 
ethnic origin and education give influence towards entrepreneurial intention, while the factors of socio-economic and cultural are also important. Ranwala (2016) also has proven that family background and entrepreneurial knowledge influence the creation of venture mediated by entrepreneurship education. Moreover, personal role model, which can be found in a family, can give learning opportunities and lead to a high self-efficacy and choose entrepreneur as a career (BarNir, Watson, \& Hutchins, 2011).

Based on the literature explanation stated above, it can be concluded that there is a relationship between family background and self-efficacy, as well as family background and entrepreneurial intention. Thus, the researcher hypothesised that:

H1. Family Background influences Entrepreneurial Self-Efficacy.

H2. Family Background influences Entrepreneurial Intention.

\subsection{Entrepreneurship Education}

Entrepreneurship Education (E.E.) is knowledge of skills, attitudes, thinking, and creativity to establish a business plan and to make the business expand (Fayolle, 2014). Besides, entrepreneurship education also combines the mental factors (i.e. knowledge, skill, and experience) and encouraging factors to stimulate and build the entrepreneurial intention (Locke, 2000). Students who are introduced to entrepreneurship education exhibited more personal attraction to entrepreneurship, stated internal locus of control, stronger self-efficacy, and higher perceived subjective norm towards entrepreneurship than students who have not enrolled to entrepreneurship course (Gerba, 2012).

The similar result happened in Africa, which showed that entrepreneurship education positively and significantly influences entrepreneurial intention because it exposes students to the general entrepreneurship knowledge and at the same time also enhance their ability to capture opportunities (Puni, Anlesinya, \& Korsorku, 2018). Additionally, Basu (2010) also mentioned that past entrepreneurship education has an impact on perceived behavioural control and self-efficacy, which lead to entrepreneurial intention. Entrepreneurship education can also influence a person's attitude and the perceived behavioural control which lead to the entrepreneurial intention (Kusumawardani, Widyanto, \& Deva, 2020)

Based on the literature explanation stated above, it can be concluded that there is a relationship between entrepreneurship education and self-efficacy, as well as entrepreneurship education and entrepreneurial intention. Thus, the researcher hypothesised that:

H3. Entrepreneurship Education influences Entrepreneurial Self-Efficacy

H4. Entrepreneurship Education influences Entrepreneurial Intention

\subsection{Entrepreneurial Self Efficacy}

Entrepreneurial Self-Efficacy has been described by many researchers previously, for instance, Bandura (1977) defined it as a person's ability to do something with a good result when they feel confident in their own abilities. Meanwhile, Dempsey and Jennings (2014) argued that self-efficacy is a faith in one's capacity to be able 
to create a business activity based on personal-assessment of entrepreneurial skills. Moreover, Setiawan (2014) has identified self-efficacy beliefs that can be established more strongly after such tasks have been completed and are expected to achieve high rates of feasibility when entrepreneurial knowledge is revealed.

Dempsey and Jennings (2014) discovered that convincing self-confidence to perform such actions requires a variety of factors to endorse the idea, while enactive expertise and physiological anticipation influence self-efficacy. Role models, leadership, work experience and emotional arousal also become the factors affecting self-efficacy, according to Santoso (2016). According to Renko, et al. (2015), Setiawan (2014), and Santoso (2016), creativity, management, and risktaking were conducted to measure the effectiveness towards self-efficacy. Furthermore, Farrukh et al. (2017) also mentioned that a person's belief in his or her capabilities has an impact on the intention to be an entrepreneur and start a new business.

Based on the literature explanation stated above, it can be concluded that there is a relationship between entrepreneurship self-efficacy and entrepreneurial intention. Thus, the researcher hypothesised that:

H5. Entrepreneurial Self-Efficacy Influences Entrepreneurial Intention

\subsection{Entrepreneurial Intention}

According to Fietze and Boyd (2017), the Theory of Planned Behaviour by Ajzen (2002) is one of the most significant models to explain the behaviour of human. The theory is supported by empirical evidence and forecasted the intention to perform behaviour through perceived behavioural control, attitudes, and subjective norms (Ajzen, 1991). Although the original founding of the theory is based on the approach of psychology, currently the model has been used in various field of research, including entrepreneurship to predict the Entrepreneurial Intention (Liñán and Chen, 2009; Carr and Sequeira, 2007; Heuer and Kolvereid, 2014).

Wang, Lu, and Millington (2011) stated that beliefs, motives, and perceptions of the person could impact the intention to start a business and to form the intention, teachers, advisors, and consultants can help to trigger the intention. Entrepreneurial intention is defined as human behavioural activity that encourages them to pursue information, to develop an idea and to carry out a business plan in order to be an entrepreneur (Tiwari, Bhat, \& Tikoria, 2017). Similar from other research, Elali and Al-Yacoub (2016) have claimed that entrepreneurial intention is a person's motivation to start and drive for the introduction of a new commercial venture from the understanding of opportunities and self-confidence towards ability will improve entrepreneurial intention in the future. Thus, from all of the researches have been conducted, it can be concluded that entrepreneurial intention is a condition where someone is equipped with motivation to establish new business and become an entrepreneur.

The entrepreneurial intention has been conducted in numerous studies to measure the attractiveness of being entrepreneurs as a career choice among students. Laviolette, Lefebvre and Brunel (2012), and Wang et al. (2011) have discovered that the potential for participation in business can be assessed by the entrepreneurial goal of the students. Moreover, it has also proven that entrepreneurial intention can 
be influenced or increased through entrepreneurial education (Pedrini, 2017), family background (Marques, Santos, \& Justino, 2018), and self-efficacy with its three dimensions, namely support on financial support, risk-taking and marketing (Fini, Grimaldi, Marzocchi, \& Sobrero, 2009).

\section{Research Method}

\subsection{Research Method}

The researcher used the questionnaire as an instrument of the research. The researcher used 7-Likert scales because 7-Likert scales have a criterion of validity, reliability, the strength of discrimination, and the stability are quite good (Budiaji, 2013). Sauro (2010) stated that 7-point Likert scales are slightly better than the 5point due to the excellent balance of including enough points of discrimination, but at the same time do not have to maintain many response options. Seven level-Likert scales are used as the answer to the questionnaire, one means strongly disagree, and seven means strongly agree (William, 2014). The questionnaire divided into five parts. The first part is questions to filter the sample per this research limitation. Questions are including Indonesia Chinese ethnicity and who studied business or entrepreneurship and having a parent as entrepreneurs and in the age of 17-22 years old. The second is demographic questions which are gender, age, education, and domicile as the fundamental question. The third parts are independent variable; there are two independent variables; entrepreneurship education and family background. The fourth part is the mediating variable, which is entrepreneurial selfefficacy, and the last part is the dependent variable, which is entrepreneurial intention.

According to Hanlon and Larget (2011), Population is all the individuals in an area, and sampling is a subset of the individuals in a population. The population in this research is Indonesian Chinese. According to Puni and Anlesinya (2018), the sample size is some population chosen for a questionnaire survey. Therefore, the researcher sample is Indonesia Chinese who studied in business or entrepreneur, and the parents is an entrepreneur and with the age range of $17-22$ years old. Recommended sample size based on Adekiya and Ibrahim (2016) minimum sample size is 200 respondents. There are two types of sampling technique which are probability and non-probability (Mohamad, Lim, \& Yusof, 2015). In this research, the researcher used non-probability test or non-random sampling. The researcher used purposive sampling as the type of non-probability techniques to get specific respondents (Crossman, 2018).

In this study, the method that is used to collect the data needed from respondents is through an online survey via Google Form in Google Drive. The data collected with the total number of 315 . The screening result and data check reveal that only 202 data were valid because 80 responses are stopped in the screening question, and 33 data were invalid. The respondents' answer is saved in Microsoft Excel in the format of raw data and then analysed in the statistical program to test the validity and reliability. Finally, to test the hypothesis and framework model, this study used Structural Equation Model through AMOS. The questionnaire distributed via online applications such as Line, WhatsApp, Facebook, and Instagram. The theoretical framework of this study can be seen in Figure 3.1, while the respondent profile can be seen in Table 3.1. 


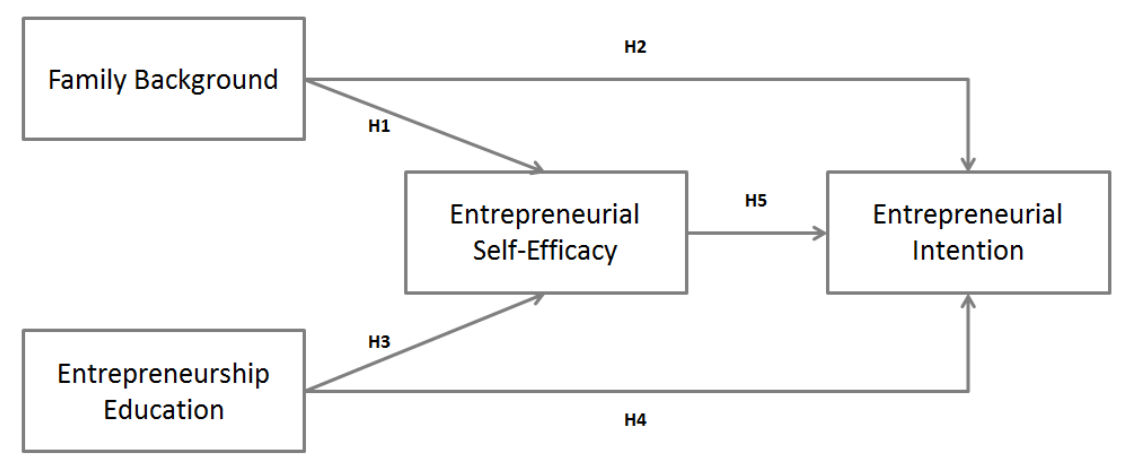

Figure 3.1 - Theoretical Framework

\begin{tabular}{|c|c|c|c|}
\hline & Category & Total & Percentage \\
\hline \multirow[t]{4}{*}{ Age } & $17-18$ & 44 & $21,70 \%$ \\
\hline & $19-20$ & 27 & $13,30 \%$ \\
\hline & $21-22$ & 131 & $65,00 \%$ \\
\hline & Total & 202 & $100 \%$ \\
\hline \multirow{4}{*}{$\begin{array}{l}\text { Current } \\
\text { Education }\end{array}$} & SMA & 25 & $12,38 \%$ \\
\hline & SMK & 21 & $10,40 \%$ \\
\hline & University & 156 & $77,22 \%$ \\
\hline & Total & 202 & $100 \%$ \\
\hline \multirow[t]{18}{*}{ Domicile } & $\begin{array}{l}\text { Central } \\
\text { Sulawesi }\end{array}$ & 1 & $0,49 \%$ \\
\hline & Batam & 1 & $0,49 \%$ \\
\hline & South Sulawesi & 2 & $0,99 \%$ \\
\hline & East Borneo & 2 & $0,99 \%$ \\
\hline & North Sulawesi & 2 & $0,99 \%$ \\
\hline & Kepulauan Riau & 2 & $0,99 \%$ \\
\hline & Bima & 3 & $1,48 \%$ \\
\hline & South Sumatra & 3 & $1,48 \%$ \\
\hline & Aceh & 5 & $2,47 \%$ \\
\hline & Jambi & 6 & $3,00 \%$ \\
\hline & Bali & 6 & $3,00 \%$ \\
\hline & West Borneo & 9 & $4,45 \%$ \\
\hline & North Sumatra & 12 & $6,00 \%$ \\
\hline & West Java & 17 & $8,41 \%$ \\
\hline & Bangka & 26 & $13,00 \%$ \\
\hline & Belitung & & \\
\hline & Greater Jakarta & 105 & $52,00 \%$ \\
\hline & Total & 202 & $100 \%$ \\
\hline
\end{tabular}




\begin{tabular}{|llll|}
\hline $\begin{array}{l}\text { Monthly } \\
\text { Allowance }\end{array}$ & $<$ Rp 1 million & 48 & $23,60 \%$ \\
\hline & Rp 1mio - 2mio & 22 & \\
& Rp 2mio - 3mio & 56 & $10,80 \%$ \\
& $>$ Rp3mio & 76 & $27,60 \%$ \\
& Total & 202 & $38,00 \%$ \\
\hline $\begin{array}{l}\text { Respondent Has } \\
\text { A Business }\end{array}$ & Yes & 83 & $100 \%$ \\
\hline & No & 119 & $41,08 \%$ \\
& Total & 202 & $58,91 \%$ \\
\hline
\end{tabular}

\subsection{Validity and Reliability Test}

According to Surbhi (2017), validity is the degree to which the score of measurement represents the intended variable concerned by the researcher. The validity used in this study is a construct validity, which consists of convergent validity and discriminant validity. Convergent validity is measuring the same construct correspond while discriminant validity does not measure what it should not (Shuttleworth, 2009). This method measures a scale or tests the construct competently in SPSS, which is why this method is chosen.

According to Field (2013), There are five factors in order to analyse is valid or not. The criteria, according to Field:

KMO (Kaiser-Meyer-Olkin) should be above or equal to 0.5 (KMO $\geq 0.5$ ); Bartlett's test should less than or equal to 0.05 (Sig. $\leq 0.05$ ); Communalities should be greater than or equal to 0.5 (Communalities $\geq 0.5$ ); Total Variance Explained should be higher or equal to 60\%; Component Matrix should be above 0.5 .

Reliability is an instrument that can be interpreted consistently. To make sure the variable is reliable or not, the researcher used Cronbach's Alpha equation. The value of Cronbach's Alpha should above than 0.6 (George \& Mallery, 2000). The details of the validity and reliability tests can be seen in Table 3.2 and Table 3.3. In summary, from the entire criterion of validity and reliability, the result passed the requirement, which implies that all the variables reported being valid and reliable.

\section{KMO and Bartlett's Test}

\begin{tabular}{|c|l|}
\hline Kaiser-Meyer-Olkin Measure of Sampling Adequacy. & 909 \\
Bartlett's Test of Sphericity Approx. Chi-Square & 2694.197 \\
Df & 66 \\
Sig. & .000 \\
\hline
\end{tabular}

Table 3.2. KMO and Bartlett's Test Result 


\begin{tabular}{|c|c|c|c|}
\hline Constructs and Indicators & $\begin{array}{l}\text { Commu } \\
\text { nalities }\end{array}$ & $\begin{array}{l}\text { Rotated } \\
\text { Comp. } \\
\text { Matrix }\end{array}$ & $\begin{array}{l}\text { Cronbach } \\
\text { 's } \alpha\end{array}$ \\
\hline Family Background & & & 0.937 \\
\hline $\begin{array}{l}\text { Having a background in the family business help } \\
\text { me to be responsive to make innovation to make the } \\
\text { business become sustainable }\end{array}$ & ,668 & ,760 & \\
\hline $\begin{array}{l}\text { In a family business, a family member can } \\
\text { understand and regulate the emotions other family } \\
\text { members }\end{array}$ & ,846 & ,885 & \\
\hline $\begin{array}{l}\text { My family background is an important aspect that } \\
\text { shapes my intention to be an entrepreneur }\end{array}$ & ,801 & ,862 & \\
\hline Entrepreneurship Education & & & 0.958 \\
\hline $\begin{array}{l}\text { Through the business or entrepreneurship course, I } \\
\text { learn about skill, knowledge, and competence to } \\
\text { develop and manage the business }\end{array}$ & .934 & .882 & \\
\hline $\begin{array}{l}\text { Entrepreneurship course makes me more aware of } \\
\text { my duties to become the entrepreneur }\end{array}$ & .924 & .858 & \\
\hline $\begin{array}{l}\text { Entrepreneurship course makes me know about } \\
\text { how to become an entrepreneur }\end{array}$ & .928 & .892 & \\
\hline Entrepreneurial Self-Efficacy & & & 0.938 \\
\hline I can give the solution when I have a problem & .943 & .784 & \\
\hline $\begin{array}{l}\text { I have the ability to develop an entrepreneurial } \\
\text { project }\end{array}$ & .871 & .691 & \\
\hline $\begin{array}{l}\text { I can find the opportunities for new product and } \\
\text { service }\end{array}$ & .878 & .613 & \\
\hline Entrepreneurial Intention & & & 0.949 \\
\hline I want to build my own business to express myself & .894 & .850 & \\
\hline $\begin{array}{l}\text { I want to become an entrepreneur rather than an } \\
\text { employee }\end{array}$ & .906 & .859 & \\
\hline Creating a business is my objective career & .927 & .871 & \\
\hline
\end{tabular}

Table 3.3. Measurement Model Result

\subsection{Inferential Analysis}

The inferential analysis is carried out using AMOS software, with a graph following the theoretical structure model, namely Entrepreneurship Education, and Family Background as Exogenous variables. Also, Entrepreneurial Intention and Entrepreneurial Self-Efficacy as Endogenous variables.

The researcher examined the error in each item to analyse unobserved variables and set the correlation arrow depending on the modification indices suggested by AMOS (intra-variable). The researcher then positioned the correlation arrow between all four variables. In the model fit review, this study carried out seven indicators with the following result. CMIN is 1.738, GFI is 0.942, AGFI is 0.902, IFI is 0.987 , TLI is 0.982 , CFI is 0.987 , and RMSEA is 0.061 . The result of the model fit can be seen in Table 3.4. 


\begin{tabular}{|l|l|l|l|}
\hline Indicator & Cut-Off Value & Result & Evaluation \\
\hline CMIN/DF & $\begin{array}{l}0.05 \leq \text { CMIN/DF } \\
\leq 5\end{array}$ & 1.738 & Good Fit \\
\hline RMSEA & $\begin{array}{l}0.05 \leq \text { RMSEA } \leq \\
0.08\end{array}$ & 0.061 & Good Fit \\
\hline TLI & TLI $\geq 0.90$ & 0.982 & Good Fit \\
\hline CFI & $0.5 \leq$ CFI $\leq 0.9$ & 0.987 & Marginal Fit \\
\hline IFI & $0.5 \leq \mathrm{IFI} \leq 0.9$ & 0.987 & Marginal Fit \\
\hline GFI & $0.80 \leq$ GFI $\leq 0.90$ & 0.942 & Marginal Fit \\
\hline
\end{tabular}

Table 3.4. Model Fit Result

After the Goodness of Fit test has been carried out, the five hypotheses in this study were tested. There are three hypotheses out of five accepted with the $p$ value equal or lower than 0.05 , and C.R. more than 1.96, namely: [H1] FB $\Rightarrow \operatorname{ESE}(* * * ; 7,688)$, [H3] $\mathrm{EE}=>\mathrm{ESE}(* * * ; 5,663),[\mathrm{H} 5] \mathrm{ESE}=>\mathrm{EI}(* * * ; 9,588)$. Two hypotheses that are rejected are [H2] FB $\Rightarrow$ EI $(, 273 ; 1,096)$, and [H4] EE $=>$ EI $(-, 609 ; 0,542)$. The result summarized in Table 3.5 .

The Squared Multiple Correlations analyse that ESE present $48.2 \%$ of its variance, mean the rest $51.8 \%$ is the error of the variable or presented by other factors that are not included in this study. It also applied to E.I. with present $65.4 \%$, and rest $34.6 \%$.

\begin{tabular}{|c|c|c|c|c|c|c|}
\hline Hypothesis & Path & Estimate & S.E & C.R & P-Value & Decision \\
\hline H1 & $\begin{array}{c}\text { FB } \rightarrow \\
\text { ESE }\end{array}$ & 0,557 & 0,072 & 7,688 & $* * *$ & Accepted \\
\hline H2 & $\begin{array}{c}\text { FB } \rightarrow \\
\text { EI }\end{array}$ & 0,085 & 0,078 & 1,096 &, 273 & Rejected \\
\hline H3 & $\begin{array}{c}\text { EE } \rightarrow \\
\text { ESE }\end{array}$ & 0,294 & 0,052 & 5,663 & $* * *$ & Accepted \\
\hline H4 & $\begin{array}{c}\text { EE } \rightarrow \\
\text { EI }\end{array}$ & $-0,030$ & 0,050 &,- 609 &, 542 & Rejected \\
\hline H5 & $\begin{array}{c}\text { ESE } \rightarrow \\
\text { EI }\end{array}$ & 0,781 & 0,081 & 9,588 & $* * *$ & Accepted \\
\hline
\end{tabular}

Table 3.5. Result of Hypothesis Testing

\section{Result and Discussion}

The first hypothesis "H1: Family background influences entrepreneurial selfefficacy" is accepted. This result indicated the same result as the study from Shittu, Ayodele, Dosunmu and Zainab (2014). They proved that family background is one of the important things for entrepreneurial self-efficacy. Besides, the journal is written by Shittu, Ayodele, Dosunmu and Zainab (2014) also stated that not only family background influences entrepreneurial self-efficacy, but experience and intention, venture feasibility and venture desirability can also influence entrepreneurial self-efficacy. 
The second hypothesis "H2: Family background influences entrepreneurial intention" is rejected. This result was different from the previous study by Marques, Santos, Galvao, Mascarenhas, and Justino (2018). They proved family background influences entrepreneurial intention. Based on Foster (2018), gen-Z is so familiar with the internet, smartphone and social media, so that they use their technology skills to build the business. In other words, gen $\mathrm{Z}$ does not really need a family who is having entrepreneurship background to choose a career in entrepreneurship. They are now exposed by many role models outside of their inner circle, or in this case, is family, through the Internet.

The third hypothesis "H3: Entrepreneurship education influences entrepreneurial self-efficacy" is accepted, and the previous study from Chen (1998) also stated the same result. Besides, Chen (1998) also stated that not only entrepreneurship education influences entrepreneurial self-efficacy, but also risk-taker trait, management, finance control, and marketing could also influence entrepreneurial self-efficacy.

The fourth hypothesis "H4: Entrepreneurship education influences entrepreneurial intention" is rejected. This result was different from the previous study by Pedrini (2017) that proved entrepreneurship education influences entrepreneurial intention. Moreover, according to Vina (2015), entrepreneurship education not always influences entrepreneurial intention, gen- $Z$ is choosing to skip college or university, and directly open a business. Gen-Z prefers to study in a workplace than study at school (Powers, 2018)it can be seen from the most successful company. For example, Mark Zuckerberg as the co-founding Facebook, he did not study entrepreneurship education, but he studied information and technology (Schawbel, 2017)

The last hypothesis "H5: Entrepreneurial self-efficacy influences entrepreneurial intention" is supported in this research. The previous study from Fini (2014) also stated the same result; she proved that entrepreneurial self-efficacy influences entrepreneurial intention. Besides, Fini (2014) also stated that not only entrepreneurial self-efficacy influences entrepreneurial intention but financial support, risk-taking and marketing could also influence entrepreneurial intention.

\section{Conclusion and Recommendation}

\subsection{Limitation}

This study has several limitations and gaps which need to be considered and addressed in future research. This study does not provide a number of elements such as work experience like in Sanchez et al. (2017), entrepreneurial behaviour like in Ajzen I. (1991), also not include cultural factors like in Sanchez et al. (2017) and gender like in Feder and Niţu-Antonie (2017) as variables but only as additional analysis.

\subsection{Recommendation}

The researcher recommends future research to add other variables, such as perceived behaviour control and attitude towards entrepreneurship. This previous study by Farooq and Salam (2018), stated that behaviour control and attitude towards entrepreneurship would impact entrepreneurial intention because to build a business people need have good behaviour and the right attitude to become a successful person. Furthermore, future research needs to add gender in demography 
respondent. This previous study by Miranda (2017), stated that gender would impact entrepreneurial intention because the characteristic of the people such as risk-taking, achievement orientation and dominance, which are more strongly linked to men than women.

This research is focusing on a particular group, which is Chinese Indonesian. The future research can expand the scope of the research to investigate other groups in Indonesia, for instance, the largest ethnic group in Indonesia; the Javanese. Based on the research by Hermawan, Arief and Rahayu (2018), the Javanese has exceptional value and guidelines which can shape the entrepreneurship behaviour in the family business.

\section{References}

Adekiya, A. A., \& Ibrahim, F. (2016, March 15). Entrepreneurship intention among students. the antecedent role of culture and entrepreneurship training and development. The International Journal of Management Education, 14(2), 116-132.

Ajzen, I. (1991). The Theory of Planned Behavior. Organisational Behavior and Human Decision Processes 50, 50(2), 179-211.

Ajzen, I. (2002). Perceived Behavioral Control, Self-Efficacy, Locus of Control, and the Theory of Planned Behavior. Journal ofApplied Social Psychology, 32(4), 665-68.

Bandura, A. (1977). Social learning theory (Vol. 43). Englewood Cliffs: PrenticeHall.

BarNir, A., Watson, W. E., \& Hutchins, H. M. (2011). Mediation and Moderated Mediation in the Relationship Among Role Models, Self-Efficacy, Entrepreneurial Career Intention, and Gender. Journal of Applied Social Psychology, 2011, 41, 2, 270-297.

Basu, A. (2004). Entrepreneurial aspirations among family business owners: An analysis of ethnic business owners in the U.K. International Journal of Entrepreneurial Behavior \& Research, 10(1-2), 12-33.

Basu, A. (2010). Comparing Entrepreneurial Intentions among Students: The Role of Education and Ethnic Origin. AIMS International Journal of Management, 4(3), 163-176.

Budiaji, W. (2013, December). Skala Pengukuran dan Jumlah Respon Skala. Jurnal Ilmu Pertanian dan Perikanan, 2(2), 127-133.

Carree, M. A., \& Thurik, A. R. (2010). The Impact of Entrepreneurship on Economic Growth. In Z. J. Acs, \& D. B. Audretsch, Handbook of Entrepreneurship Research (pp. 557-594). New York: Springer.

Chen, C. C., Greene, P. G., \& Crick, A. (1998). Does entrepreneurial self-efficacy distinguish entrepreneurs from managers? Journal of Business Venturing, 13(4), 295-316. doi:10.1016/s0883-9026(97)00029-3

Crossman, A. (2018, September 28). Understanding Purposive Sampling. Retrieved April 5, 2019, from ThoughtCo.: 
https://www.thoughtco.com/purposive-sampling-3026727

Dempsey, D., \& Jennings, J. (2014). Gender and Entrepreneurial Self-Efficacy: A Learning Perspective. Gender and Entrepreneurship, 6(1), 28-49.

Drennan, J., Kennedy, J., \& Renfrow, P. (2005). Impact of childhood experiences on the development of entrepreneurial intentions. The International Journal of Entrepreneurship and Innovation, 6(4), 231-238.

Dwinanda, R. (2018, October 18). Indonesia's entrepreneurship rate low: Enggartiasto. Retrieved April 1, 2019, from Republika: https://www.republika.co.id/berita/en/nationalpolitics/18/10/18/pgsvvf414-indonesias-entrepreneurship-rate-lowenggartiasto

Elali, W., \& Al-Yacoub, B. (2016). "Factors affecting entrepreneurial intentions among Kuwaitis. World Journal of Entrepreneurship, Management and Sustainable Development, 12(1), 18-34.

Farooq, M. S., \& Salam, M. (2018, March 27). Impact of support from social network on entrepreneurial intention of fresh business graduates: A structural equation modelling approach. Education + Traning, 23(1), 335353. Retrieved from The Many Different Types of Video Games \& Their Subgenres: https://doi.org/10.1108/ET-06-2017-0092

Farrukh, M., Khan, A. A., Khan, M. S., Ramzani, S. R., \& Soladoye, B. S. (2017). Entrepreneurial intentions: the role of family factors, personality traits and self-efficacy. World Journal of Entrepreneurship, Management and Sustainable Development, 13(4), 303-317.

Fayolle. (2014). Entrepreneurship Education in Europe: Trends and Challenges. Journal of European Industrial Training, 30(9), 1-12.

Feder, E.-S., \& Niţu-Antonie, R.-D. (2017). Connecting gender identity, entrepreneurial training, role models and intentions. International Journal of Gender and Entrepreneurship, 9(1), pp.87-108.

Field, A. (2013). Discovering Statistics Using IBM SPSS Statistics. London: Sage Publications Ltd.

Fietze, S., \& Boyd, B. (2017). Entrepreneurial intention of Danish students: a correspondence analysis. International Journal of Entrepreneurial Behavior \& Research, 23(4), 656-672.

Fini, R. (2014). The Foundation of Entrepreneurial Intention. Journal of Technology Transfer, 14(2), 1-40. Retrieved from http://ssrn.com/abstract $=1313225$

Fini, R., Grimaldi, R., Marzocchi, G. L., \& Sobrero, M. (2009). The Foundation of Entrepreneurial Intention.

Foster, T. (2018, August 25). This Entrepreneur Hit Rock Bottom Before Building a Billion-Dollar Jewelry Empire (With Only \$500). Retrieved December 19, 2018, from www.inc.com: https://www.inc.com/benjamin-p-hardy/themost-potent-gen-z-entrepreneurial-panel-assembled.html

George, D., \& Mallery, P. (2000). SPSS for Windows Step by Step: A Simple Guide and Reference. Boston: Pearson A and B. 
Gerba, D. T. (2012). Impact of entrepreneurship education on entrepreneurial intentions of business and engineering students in Ethiopia. African Journal of Economic and Management Studies, 3(2), 258 - 277.

Globe Asia. (2018, June). 150 RICHEST INDONESIANS. Retrieved April 1, 2019, from Globe Asia: https://www.globeasia.com/cover-story/150-richestindonesians-2/

Hanlon, B., \& Larget, B. (2011, September 8). Samples and Populations. Department of Statistics University of Wisconsin-Madison, 14(2), 10-22.

Heriyanto, D. (2019, February 4). Times they are a-changin': Legacy of ChineseIndonesian family businesses . Retrieved April 1, 2019, from The Jakarta Post: https://www.thejakartapost.com/life/2019/02/04/times-they-are-achangin-legacy-of-chinese-indonesian-family-businesses.html

Hermawan, A., Arief, M., \& Rahayu, W. P. (2018). Dimensions of the Javanese culture and the role of parents in instilling values in creative industry entrepreneurship. International Journal of Engineering \& Technology, 7(2), 182-189.

Indonesia Investments. (2018). Unemployment in Indonesia. Retrieved April 1, 2019, from Indonesia Investments: https://www.indonesiainvestments.com/finance/macroeconomicindicators/unemployment/item255?

Kerr, W. R., \& Mandorff, M. (2015, September). Social Networks, Ethnicity, and Entrepreneurship. Working Paper Series 21597. National Bureau of Economic Research.

Koning, J. (2007). Chineseness and Chinese Indonesian Business Practices: A Generational and Discursive Enquiry. East Asia, 24(2), 129-152.

Kumar, S., \& Prameswari, Q. (2018). The Determinants of a Successful Family Business Succession in Indonesia: A Multiple Case Study. International Journal of Family Business, 1(2), 87-103.

Kusumawardani, K. A., Widyanto, H. A., \& Deva, I. P. (2020). Understanding the entrepreneurial intention of female entrepreneurs in the Balinese tourism industry: Superman is Dead. International Journal of Research in Business and Social Science, 9(1), 63-79. DOI:10.20525/ijrbs.v9i1.611

Laviolette, E. M., Lefebvre, M. R., \& Brunel, O. (2012). The impact of story bound entrepreneurial role models on self-efficacy and entrepreneurial intention. International Journal of Entrepreneurial Behavior \& Research, 18(6), 720742.

Lestari, D., \& Darmawan, Z. (2018, November 1). Wirausaha Indonesia Masih Tergolong Sedikit untuk Jadi Negara Maju. Retrieved April 1, 2019, from Viva: https://www.viva.co.id/berita/bisnis/1089839-wirausaha-indonesiamasih-tergolong-sedikit-untuk-jadi-negara-maju

Liñán, F., \& Fayolle, A. (2015). A systematic literature review on entrepreneurial intentions: citation, thematic analyses, and research agenda. International Entrepreneurship and Management Journal, 11(4), 907-933.

Liñán, F., Rodríguez-Cohard, J. C., \& Rueda-Cantuche, J. M. (2010). Factors 
affecting entrepreneurial intention levels: a role for education. International Entrepreneurship and Management Journal, 7(2), 195-218.

Locke, E. A. (2000). The Prime Movers: Traits of the Great Wealth Creators. New York: AMACOM.

Marques, C., Santos, G., \& Justino, E. (2018). Entrepreneurship education, gender and family background as antecedents on the entrepreneurial orientation of university student. International Journal of Innovation, 10(1), 58-70.

Matthews, \& Moser. (2016). Longitudinal investigation of the impact of family background and gender on interest in small firm ownership. Journal of Small Business Management, 2(2), 110 - 129.

Miranda, J. (2017, Febuary 14). Academic Entrepreneurial Intention: The Role of Gender. International Journal of Gender and Entrepreneurship, 9(1), 6686. Retrieved from http://dx.doi.org/10.1108/IJGE-10-2016-0037

Mohamad, N., Lim, H. E., \& Yusof, N. (2015, september 30). Estimating the Effect of Entrepreneurship Education on Graduates' Intention to be Entrepreneurs. Education + Training, 57(8/9), 874-890.

Pedrini. (2017). Do entrepreneurial education programs impact the antecedents of entrepreneurial intention? Journal of Enterprising Communities: People and Places in the Global Economy,, 11(3), 373-392.

Powers, A. (2018, July 31). Why Gen-Z Talent Is More Likely To Pursue Entrepreneurship. Retrieved November 18, 2018, from forbers: https://www.forbes.com/sites/annapowers/2018/07/31/why-gen-z-talentis-more-likely-to-pursue-entrepreneurship/\#6814991c7822

Puni, A., \& Anlesinya , A. (2018). Entrepreneurial education, self-efficacy and intentions in sub saharan Africa. African Journal of Economic and Management Studies, 12(2), 124-134. Retrieved from https://doi.org/10.1108/AJEMS-09-2017-0211

Puni, A., Anlesinya, A., \& Korsorku, P. D. (2018). Entrepreneurial education,selfefficacy and intentions in Sub-Saharan Africa. African Journal of Economic and Management Studies, 9(4), 492-511.

Ranwala, R. S. (2016). Family Background, Entrepreneurship Specific Education and Entrepreneurial Knowledge in Venture Creation. International Journal of Scientific and Research Publications, 6(9), 495-501.

Renko, M., Tarabishy, A. E., Carsrud, A. L., \& Brännback, M. (2015). Understanding and Measuring Entrepreneurial Leadership Style. Journal of Small Business Management, 53(1), 69-98.

Sanchez, A. A., Soler, S. B., \& Hernandez, A. J. (2017). A missing link: the behavioral mediators between resources and entrepreneurial intentions. International Journal of Entrepreneurial Behavior \& Research, 23(5), 752768.

Santoso, A. B. (2014, December 10). Analysis: Current condition of Indonesia's entrepreneurs. Retrieved April 1, 2019, from The Jakarta Post: https://www.thejakartapost.com/news/2014/12/10/analysis-currentcondition-indonesia-s-entrepreneurs.html 
Santoso, S. (2016). Influence Of Self-Efficacy To Student EntrepreneurialIntention With Student Background As A Moderating Variable: Case Study In Indonesia. International Journal of Information, Business and Management, 8(4), 131-144.

Sauro, J. (2010, August 25). Should You Use 5 or 7 Point Scales. Retrieved April 5, 2019, from Measuring U: https://measuringu.com/scale-points/

Schawbel, D. (2017, Febuary 16). Millenials might not be as entrepreneurial as you think. Retrieved November 18, 2018, from weforum: https://www.weforum.org/agenda/2017/02/millennials-arent-theentrepreneurial-generation-you-might-think-they-are

Setiawan, J. L. (2014). Examining Entrepreneurial Self-Efficacy among Students. Social and Behavioral Sciences, 115, 235-242.

Setijadi, C. (2016, March 17). Ethnic Chinese in Contemporary Indonesia: Changing Identity Politics and the Paradox of Sinification. ISEAS Perspective, 2016(12).

Shittu, Ayodele, Dosunmu, \& Zainab. (2014). Family Background and Entrepreneurial Intention of Fresh Graduates in Nigeria. Journal of Poverty, Investment and Development, 5(1), 78-88.

Shuttleworth, M. (2009, November 8). Types of Validity. Retrieved January 28, 2019, from Explorable: https://explorable.com/types-of-validity

Surbhi. (2017, March 9). Difference Between Validity and Reliability. Retrieved January 28, 2019, from Key Differences: https://keydifferences.com/difference-between-validity-andreliability.html

Sutanto, O., \& Nurrachman, N. (2018). Makna Kewirausahaan Pada Etnis Jawa, Minang, Dan Tionghoa: Sebuah Studi Representasi Sosial. Jurnal Psikologi Ulayat, 5(1), 86-108.

Tiwari, P., Bhat, A. K., \& Tikoria, J. (2017). "Predictors of social entrepreneurial intention: an empirical study. South Asian Journal of Business Studies, 6(1), 53-79.

Trading Economics. (2018). Unemployment Rate | Asia. Retrieved April 1, 2019, from Trading Economics: https://tradingeconomics.com/countrylist/unemployment-rate?continent=asia

Vina. (2015, September 17). Alasan Kenapa Murid Nakal Ternyata Bisa Lebih Sukses. Retrieved September 22, 2018, from Liputan6.

Wang, W., Lu, W., \& Millington, J. K. (2011). Determinants of Entrepreneurial Intention among College Students in China and USA. Journal of Global Entrepreneurship Research, 1(1), 35-44.

William. (2014). How to Write and analyse a questionnaire. Internation Journal of Academic Research, 2(2), 245-252.

World Population Review. (2019). Total Population by Country 2019. Retrieved April 1, 2019, from World Population Review: http://worldpopulationreview.com/countries/ 